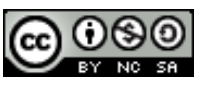

https://doi.org/10.31743/abmk.11776

JANUSZ ŁOSOWSKI* - LUBLIN

\title{
PROBLEM ZASAD ETYCZNYCH W PRACY POLSKICH ARCHIWISTÓW
}

\section{Streszczenie}

Kodeks etyczny archiwisty uchwalony w roku 1996 na Międzynarodowym Kongresie Archiwów w Pekinie został w Polsce przyjęty przez środowisko archiwalne i nie wzbudzał uwag krytycznych. W artykule uzasadniono potrzebę stworzenia polskiego kodeksu etycznego archiwistów na jego podstawie i uzupełnienia o trzy zasady. Ze względu na wielką wartość dokumentacji przechowywanej w archiwach polskich należałoby uznać pracę archiwalną jako służbę na rzecz państwa i obywateli, wymagającą od archiwistów szczególnego zaangażowania oraz odpowiedzialności. Personel archiwalny powinien dążyć do udoskonalania pomocy informacyjnych, istniejących w archiwach, szczególnie w odniesieniu do zespołów najcenniejszych i udostępnianych, dla lepszego zaspokajania indywidualnych potrzeb informacyjnych obywateli, prowadzących poszukiwania w archiwach. Archiwa państwowe należałoby również zobowiązać do podejmowania działań mających na celu zabezpieczenie cennych akt posiadanych przez osoby prywatne oraz przejmowania ich na warunkach uzgodnionych z właścicielami. Gdyby okazało się to niemożliwe, mogłyby starać się o sporządzenie za ich zgodą kopii cyfrowych i udostępniania na ustalonych zasadach.

Słowa kluczowe: etyka; zasady etyczne; praca archiwistów; archiwa polskie

* Janusz Łosowski - prof. historii; Instytut Historii, Uniwersytet Marii Curie-Skłodowskiej w Lublinie; e-mail: j.losowski@poczta.umcs.lublin.pl

https://orcid.org/0000-0003-1223-4288 


\section{Wstęp}

Kwestie zasad moralnych w postępowaniu urzędników, dawniej niedoceniane, od dłuższego czasu stają się przedmiotem zainteresowania różnych grup zawodowych, dbających o przestrzeganie należnych standardów postępowania przez ich członków, ale także licznych opracowań naukowych. Problematyka ta szczególnie przyciąga uwagę prawników ${ }^{1}$ ze względu na szczególną rolę, jaką odgrywają przedstawiciele tej profesji, decydując w swojej działalności o życiu, wolności, godności, bezpieczeństwie i dobrobycie innych obywateli², występując w roli sędziów, prokuratorów, adwokatów, radców prawnych czy też urzędników administracyjnych. Jeszcze większą rolę odgrywa etyka w pracy lekarzy ${ }^{3}$, od której zależy ludzkie życie i zdrowie, a także w działalności finansowej istotnej dla wszystkich form ludzkiej aktywności ${ }^{4}$.

Praca archiwistów tylko w małym stopniu oddziałuje na ludzkie losy i nie ma na nie takiego wpływu jak czynności prawników czy też lekarzy. Tym niemniej może oddziaływać na efektywność badań prowadzonych przez historyków, poszukujących w archiwach informacji źródłowych niezbędnych do poznawania przeszłości. Archiwiści mogą też oddziaływać na stan spraw załatwianych przez pojedynczych obywateli, udzielając im potrzebnych informacji lub wskazując niezbędną dla nich dokumentację. Niejednokrotnie wpływa to bezpośrednio na ich interesy finansowe, ułatwia uzyskiwanie istotnych uprawnień, umożliwiających poprawę sytuacji materialnej, prawnej czy też społecznej, a czasem podwyższających komfort życia.

Czy zatem archiwistom nie wystarczą przepisy prawa takie jak ustawa archiwalna oraz kodeks postępowania administracyjnego i należy jeszcze tworzyć odrębne zasady etyczne, bardziej szczegółowo regulujące nie tylko ich postępowanie, sposób myślenia czy też stopień wrażliwości? Potrzeba opracowania zasad etycznych wynika co najmniej z trzech powodów. Po pierwsze eksponowanie pryncypiów etycznych może zwiększyć świadomość obowiązków ciążących na archiwistach, co powinno wpłynąć na podniesienie poziomu ich pracy, a szczególnie najbardziej istotnego jej aspektu związanego z udostępnianiem dokumentacji zainteresowanym użytkownikom. Posiadanie zasad etycznych przez członków określonej profesji na pewno zwiększa jej prestiż w społeczeństwie. Po trzecie problemy etyki zawodowej archiwistów podejmuje się za granicą i tworzy się kodeksy etyczne, w związku z tym polskie środowisko archiwalne w żadnym przypadku nie powinno ignorować tej kwestii.

W tym przypadku byłoby lepiej, gdyby polscy archiwiści dążyli do stworzenia własnych zasad etycznych, bardziej dostosowanych do warunków dzia-

${ }^{1} \mathrm{Z}$ licznych prac warto zwrócić uwagę na takie pozycje jak: R. Sarkowicz, Amerykańska etyka prawnicza, Kraków 2004; R. Tokarczyk, Etyka prawnicza, Warszawa 2006, s. 13; H. Izdebski, Etyka prawnicza: stanowiska i perspektywy, Warszawa 2008.

${ }^{2}$ Tokarczyk, Etyka prawnicza, s. 13.

${ }^{3}$ Np. T. Kielanowski, Etyka i deontologia lekarska, red. J. Bogusz, Warszawa 1985; S. Olejnik, Etyka lekarska, Katowice 1995; T. Brzeziński, Etyka lekarska, Warszawa 2002.

${ }^{4}$ Przykładowo: Etyka w biznesie, red. P.M. Minus, tłum. E. Balcerek, Warszawa 1998; P. Pratley, Etyka w biznesie, przekł. M. Albigowski, Warszawa 1998. 
łania archiwów w naszym kraju. Celem tego artykułu jest nie tylko zwrócenie uwagi na problemy etyczne pracy archiwalnej, ale także wskazanie zasad, które powinny zostać uwzględnione w kodeksie etycznym polskich archiwistów, który powstanie zapewne w przyszłości. Ograniczone ramy artykułu nie pozwalają na uwzględnienie wszystkich problemów związanych z problematyką etycznych podstaw profesji archiwalnej. Można mieć nadzieję, że ten tekst skłoni szersze grono jej członków do większego zainteresowania zasadami wykonywanej przez nich pracy, co być może wpłynie na podniesienie jej poziomu oraz pogłębienie świadomości specyfiki dyscypliny naukowej jaką jest archiwistyka.

\section{Przegląd badań}

Uznaje się, że podstawę teoretyczną rozważań etycznych dostarczyła praca angielskiego archiwisty H. Jenkinsona, który w swojej klasycznej pracy zwrócił uwagę na ciążący na archiwistach moralny obowiązek zachowania dokumenta$\mathrm{cji}^{5}$. Pierwszy kodeks archiwalny został opracowany w USA przez Archiwum Narodowe w roku 1955 i został wykorzystany w szkoleniu archiwistów. Prace nad nowym kodeksem podjęto pod wpływem sprawy prof. Francisa Loewenheima, który w roku 1969, zarzucił pracownikom Biblioteki Prezydenta Franklina Delano Roosevelta, że niewłaściwie archiwizowali dokumentację i wykorzystywali ją dla własnych celów ${ }^{6}$. W następstwie tego Stowarzyszenie Archiwistów Amerykańskich powołało komisję do spraw etyki, która opracowała w roku 1980 pierwszy „Kodeks etyki archiwistów”, opatrzony komentarzami pozwalającymi lepiej zrozumieć jego zasady. Opracowanie to zostało zatwierdzone przez Stowarzyszenie w roku 1992. W roku 2005 kodeks zmieniono usuwając z niego komentarze.

W latach 90. ubiegłego wieku tego rodzaju normatywy etyczne zaczęły też opracowywać inne narodowe organizacje archiwalne jak Stowarzyszenie Archiwistów Kanadyjskich czy Australijskie Stowarzyszenie Archiwistów. W roku 1995 na Międzynarodowym Kongresie Archiwów w Pekinie w roku 1996 uchwalono Kodeks Etyczny Archiwisty, który zyskał międzynarodowy rozgłos, dzięki tłumaczeniu na większość języków. Tekst Kodeksu został opublikowany na stronie internetowej szwajcarskiego Stowarzyszenia Archiwistów i Archiwistek po niemiecku, a także w przekładach francuskim i włoskim ze względu na występowanie tych języków w Szwajcarii. Dodatkowo dołączono też do nich angielską wersję Kodeksu? $\mathrm{Z}$ treścią normatywu etycznego uchwalonego w Pekinie zapoznano także archiwistów czeskich ${ }^{8}$, jednak jego publikacja w poczytnym czasopiśmie nie wywołała dyskusji, ani też nie stała się powodem do dalszych publikacji.

W Rosji zasady kodeksu pekińskiego został przyjęte przez sektor prywatny zajmujący się świadczeniem usług archiwalnych, o czym może świadczyć zamieszczenie jego thumaczenia na stronie kompanii BiznesSerwis ${ }^{9}$, zajmującej się

${ }^{5}$ Encyclopedia of Archival Science, ed. L. Duranti, P. C. Franks, Rowman and Littlefild Publishing Group, Lanham 2015, s. 47.

${ }^{6}$ Tamże.

${ }^{7}$ https://vsa-aas.ch/beruf/ethikkodex/ (dostęp: 18.07.2019).

${ }^{8}$ Kodex etických zasád pro archiváře, „Archivní Časopis”, 48 (1998) s. 1-3.

${ }^{9}$ http://www.adok.ru/about/ (dostęp: 17.07.2019). 
przechowywaniem dokumentacji, jej brakowaniem, oprawą akt, tworzeniem ewidencji archiwalnej oraz wykazów akt. Natomiast w zasadach pracy archiwalnej wprowadzonych zarządzeniem Rosyjskiej Agencji Archiwalnej z 12 lutego $2002 \mathrm{r}$. i dostępnych $\mathrm{w}$ wersji elektronicznej ${ }^{10} \mathrm{~W}$ punkcie 3.9. sformułowano pryncypia etyczne, które nawiązywały do kodeksu przyjętego w Pekinie, jednak posiadały pewne odrębne sformułowania, odzwierciedlające specyfikę działalności archiwów w Federacji Rosyjskiej.

Funkcjonujące od roku 2010 w Wielkiej Brytanii i Irlandii Stowarzyszenie Archiwów i Dokumentacji również wprowadziło swój zbiór zasad etyki archiwalnej ${ }^{11}$. Uznało, że jest on potrzebny, ponieważ wzmacnia zaufanie do archiwistów i dokumentalistów uprawiających swój zawód i należących do stowarzyszenia. Każda osoba ubiegająca się o jego członkostwo została zobowiązana do przestrzegania zasad zawartych w tym normatywie etycznym. Dzięki temu może przeciwstawić się ewentualnej presji pracodawcy zmierzającej do zachowania niezgodnego z nimi.

W literaturze zachodniej można odnaleźć prace dotyczące etycznej strony pracy archiwalnej. Można w nich zauważyć tendencję do pomijania problemu treści zasad lub spychania go na plan dalszy. Przykładem może być artykuł Glenna Dingwalla ${ }^{12}$, poświęcony roli archiwalnych kodeksów etycznych w umacnianiu zaufania do archiwów. Powstał on na podstawie pracy magisterskiej, którą autor napisał w Szkole Studiów Bibliologicznych, Archiwalnych i Informacyjnych w Uniwersytecie Kolumbii Brytyjskiej. W roku 2003 uzyskał za nią nagrodę imieniem Theodora Calvina Pease'a, szanowanego profesora historii Uniwersytetu $\mathrm{w}$ Illinois. $\mathrm{Z}$ tego powodu została też opublikowana $\mathrm{w}$ formie artykułu $\mathrm{w}$ renomowanym amerykańskim czasopiśmie archiwalnym. G. Dingwall w swoim opracowaniu skupił uwagę na filozoficznych aspektach problematyki etycznej, praktycznie pomijając kwestię zasad pracy archiwalnej, składających się na treść tych normatywów. Charakterystyczne, że porównaniu treści kodeksów funkcjonujących w krajach anglosaskich poświęcił tylko jeden akapit, dochodząc do zaskakującego wniosku, że mimo swojego istnienia nie wzmacniają one społecznego zaufania do zawodu archiwisty ${ }^{13}$.

Zasadami pracy archiwalnej zajęła się również Elfriede Schalit w opracowaniu, które także powstało na podstawie pracy magisterskiej, obronionej w 2014 roku w Instytucie Historii Uniwersytetu w Bernie, w ramach Studium Zaawansowanych Badań Archiwalno-Biblioteczno-Informacyjnych ${ }^{14}$. Autorka zawarła w nim tezę, że kodeks uchwalony w Pekinie nie odpowiada w pełni potrzebom doby

\footnotetext{
${ }^{10} \mathrm{http}: / /$ www.zakonprost.ru/content/base/part/323656 (dostęp: 17.07.2019).

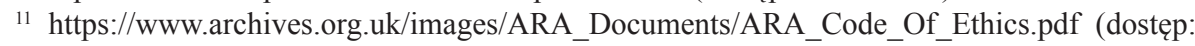
17.07.2019).

${ }^{12}$ G. Dingwall, Trusting Archivists: The Role of Archival Ethics Codes in Establishing Public Faith, „The American Archivist”, Vol. 67, 2004, Issue 1, p. 10-30.

${ }^{13}$ Tamże, p. 27.

${ }^{14}$ E. Schalitt, Auf dem Weg zur Archivethik für das Informationszeitalter. Der Kodex etischer Grundsätze für Archivarinen und Archivare im Kontext aktueller Informationsetischer Entwicklungen, „Informationswissenschaft: Theorie, Methode, Praxis”, 2016, s. 24-59.
} 
cyfrowej. Zarzuciła mu też oderwanie od etycznych podstaw filozofii. Stwierdziła też, że archiwa $\mathrm{z}$ ich problemami etycznymi mieszczą się w obrębie etyki informacyjnej, ponieważ dziedzina działań archiwów coraz bardziej się rozszerza w kierunku zarządzania zapisami, którym należy zapewnić integralność i autentyczność oraz ochraniać je przed możliwością deformacji i manipulacji. Wykorzystując prace znanych badaczy etyki informacyjnej Luciano Floridiego oraz Reinera Kuhlensa przypisała zbyt wielką wagę zasadom przydatnym w pracy $\mathrm{z}$ nowoczesną informacją $\mathrm{w}$ formie elektronicznej. Nie bardzo można zastosować je w praktyce archiwów, posiadających w swoim zasobie dokumentację w tradycyjnej formie papierowej. Teoretyczny charakter rozważań autorki spowodował, że zabrakło w nich propozycji zmiany istniejących zasad etyki archiwalnej.

Na polskim gruncie problematyka etyczna nie spotkała się z szerszym zainteresowaniem. Przegląd naszych publikacji odnoszących się do tej kwestii przyniósł zaledwie kilka pozycji, które jednak warto przypomnieć. Po raz pierwszy problem zasad etycznych w archiwistyce poruszył Zygmunt Kolankowski ${ }^{15}$, który zamieścił tekst kodeksu obowiązujący archiwistów amerykańskiego Archiwum Narodowego. W krótkiej przedmowie do tego normatywu wytłumaczył brak publikacji dotyczących etyki w polskim piśmiennictwie archiwalnym oraz pomijanie problematyki etycznej na kursach archiwalnych, oczywistością zasad postępowania archiwistów. Uznał jednak, że sprawa opracowania zasad regulujących postępowanie archiwistów stanowi pilne zadanie, ponieważ z różnych stron napływały sygnały o niedostatecznym poziomie etycznym pracowników archiwów różnych środowisk i szczebli ${ }^{16}$.

Później przez okres niemal ćwierć wieku problem etyki archiwalnej nie wzbudzał żadnego zainteresowania ze strony naszych archiwistów. Dopiero w roku 1994 wypowiedział się w tej kwestii prof. Jerzy Skowronek, ówczesny Naczelny Dyrektor Archiwów Państwowych, na międzynarodowym seminarium we włoskim Bellagio. Jednak jego uwagi bardziej dotyczyły reguł praktyki działania archiwów niż zasad etycznych o charakterze ogólnym. Opowiedział się on przeciwko podporządkowaniu kierownictwa służb archiwalnych oraz dyrektorów archiwów partiom politycznym, nadmiernemu utajnianiu dokumentacji oraz uprzywilejowaniu niektórych grup użytkowników ${ }^{17}$. Zwrócił też uwagę na potrzebę przejmowania przez archiwa akt tajnych służb bezpieczeństwa, przyśpieszonego opracowywania inwentarzy, w celu udostępniania zainteresowanym jak największej ilość akt, także pomijania okresów karencji w zakresie udostępniania w przypadku badań naukowych o znaczeniu fundamentalnym ${ }^{18}$. Wskazał również na potrzebę respektowania zasady pertynencji terytorialnej przy przechowywaniu akt, popularyzacji problemów archiwalnych w społeczeństwie, umacniania kontaktów

${ }^{15}$ Z. Kolankowski, Kilka uwag wstepnych w sprawie etyki zawodu archiwisty, „Archiwista”, 8 (1972) nr 2, s. 19-22.

${ }^{16}$ Tamże, s. 20.

${ }_{17}$ J. Skowronek, Głos w dyskusji o „,Kodeksie etycznym archiwisty”, „Archeion”, 94 (1995) s. $362-363$.

${ }^{18}$ Tamże, s. 363. 
archiwów ze szkołami oraz wypracowywania przez środowiska archiwalne zasad etycznych ${ }^{19}$.

Po odbyciu Międzynarodowego Kongresu Archiwów w Pekinie w roku 1996, na którym przyjęto kodeks etyczny archiwisty, opublikowano jego treść ${ }^{20}$, a krótki szkic poświęcony temu wydarzeniu zamieścił Władysław Stępniak ${ }^{21}$. Wyraził on też kilka interesujących spostrzeżeń. Uznał, że rozważania o etyce zawodowej muszą być poprzedzone określeniem poziomu posiadanej wiedzy i kwalifikacji zawodowych. Stwierdził też, że ze względu na różnice w organizacji archiwów i podstawie prawnej ich działania występujące w poszczególnych krajach, uwaga archiwistów powinna być skoncentrowana na najważniejszych zasadach związanych z bezpieczeństwem zasobu archiwów oraz konieczności świadczenia przez archiwa usług na rzecz wszystkich osób upragnionych. Zaliczył do nich podawanie prawdy o materiałach archiwalnych znajdujących się w archiwach, kompetencje zawodowe archiwistów oraz ich rzetelność, zaangażowanie, obiektywizm i uczciwość ${ }^{22}$. Napisał też wyraźnie, że archiwiści mają do wypełnienia misję wobec zbiorów i ich czytelników. Polega ona na odpowiedzialności za stan fizyczny zbiorów, ich naukowe opracowanie oraz służenie informacją o nich wszystkim zainteresowanym bez względu na ich wykształcenie i kompetencje ${ }^{23}$.

W ostatniej dekadzie pojawił się tylko jeden artykuł poświęcony problematyce etycznej w pracy archiwistów napisany przez Renatę Matuszak ${ }^{24}$, który powstał na podstawie pracy magisterskiej napisanej w roku $2008 \mathrm{w}$ piotrkowskiej filii Uniwersytetu Jana Kochanowskiego w Kielcach, pod kierunkiem prof. Zofii Leszczenko. Autorka zamieściła w tym artykule teksty obu wymienionych kodeksów, jednak nie ukazała różnic między nimi, ani też nie poddała ich ocenie. Zaakceptowała też większość wartości, wskazanych w szkicu W. Stępniaka. Zwróciła również uwagę na potrzebę stosowania w etyce archiwalnej zasady odpowiedzialności moralnej, zobowiązującą do przyznawania się do popełnionych błędów, ponoszenia ich konsekwencji oraz ich naprawiania w miarę możliwości ${ }^{25}$. Nie uzasadniła jednak potrzeby podniesienia tej niewątpliwej cnoty do rangi jednej z naczelnych zasad archiwalnych, co może wywoływać wrażenie, że środowisko archiwistów jest szczególnie narażone na popełnianie pomyłek w trakcie swojej pracy. Na podstawie znajomości praktyki archiwów można stwierdzić, że pod względem częstotliwość pomyłek archiwiści bynajmniej się nie wyróżniają na tle innych grup zawodowych. Cechę tę powinien posiadać każdy człowiek,

19 Tamże, s. 365.

${ }^{20}$ Tamże, s. 10-14 (w tłumaczeniu Haliny Natorf). Tekst tego normatywu jest też dostępny w formie elektronicznej pod adresem: http://sap.waw.pl/wp-content/uploads/ul/kodeks.pdf (dostęp: 14.07.2019).

${ }^{21}$ W. Stępniak, Etyczne aspekty zawodu archiwisty, „Archiwista Polski”, 1 (1997) nr 1, s. 15-17.

22 Tamże. s. 17.

23 Tamże, s. 16.

${ }^{24}$ R. Matuszak, Etyka a zawód archiwisty, „Piotrkowskie Zeszyty Historyczne”, 11 (2010) S. 207-222.

${ }^{25}$ Tamże, s. 221. 
niezależnie od wykonywanego zawodu, dlatego nie powinno się jej włączać do kodeksu etycznego archiwistów.

Dowodem zainteresowania problemami aksjologicznymi naszych archiwistów było też seminarium poświęcone zagadnieniu etyki w zawodzie archiwisty, odbyte w dniu 11 maja 2009 r. w Warszawie. Zorganizowały go Archiwum PAN oraz Polskie Towarzystwo Archiwalne. Wzięli w nim udział przedstawiciele archiwów państwowych, bibliotek, Kościoła Rzymskokatolickiego oraz innych związków wyznaniowych ${ }^{26}$. Niestety, materiały z tego sympozjum do tej pory nie zostały opublikowane. A ich upowszechnienie mogłoby wywołać dyskusję nad kwestiami etycznymi pracy polskich archiwistów.

\section{Niezbędność zasad etycznych w działalności archiwów}

Brak poważniejszej refleksji poświęconej etycznej stronie pracy archiwalnej, szczególnie archiwów państwowych, wymaga przedstawienia korzyści płynących z zajmowania się tą problematyką. Przypuszczalnie wielu archiwistów może jeszcze sądzić, że kwestie zasad pracy archiwalnej nie wymagają refleksji, ponieważ są one oczywiste, powszechnie zrozumiałe i akceptowane, co przed wielu laty zauważył Z. Kolankowski ${ }^{27}$. Z takim poglądem oczywiście nie można zgodzić się, ponieważ ich potrzebę dostrzeżono w innym kręgu, przykładowo socjologów, którzy musieli rozwiązać praktyczny problem przechowywania i udostępniania materiałów (wywiadów i ankiet) powstałych w ramach socjologicznych projektów badawczych. A kwestie z tym związane nie były pojmowane jednoznacznie przez badaczy zajmujących się wykorzystywaniem tego rodzaju dokumentacji naukowej ${ }^{28}$.

Porównanie kodeksów amerykańskiego i międzynarodowego, przyjętego w Pekinie w roku 1996, pokazuje istotne różnice między nimi. Skoro tak jest, to powinny zostać one poddane głębszej refleksji. Ponadto zbiór zasad etycznych powinien być dostosowany do odmiennej sytuacji historycznej, politycznej i kulturowej naszego kraju oraz związanej z tym odmienności zadań polskich archiwów państwowych. Przyjęcie zbioru zasad etycznych powinno przyczynić się do podniesienia poziomu pracy archiwalnej ${ }^{29}$. Można mieć nadzieję, że archiwiści akceptując je, będą opracowywali dokumentację nie tylko z większą świadomo-

${ }^{26}$ Referaty dotyczące etyki w środowisku archiwalnym wygłosili przedstawiciele archiwów państwowych: prof. Władysław Stępniak, reprezentujący też Uniwersytet Mikołaja Kopernika w Toruniu, dr Piotr Dymmel, dyrektor Archiwum Państwowego w Lublinie oraz mgr Anna Czajka, kierująca Centralnym Laboratorium Konserwacji Archiwaliów przy warszawskim Archiwum Głównym Akt Dawnych. Spojrzenie bibliotekarzy przedstawiła w swoim wystąpieniu dr Teresa Święćkowska. Z kolei stanowisko archiwów kościelnych zaprezentował ks. prof. Jan Związek ze Stowarzyszenia Archiwistów Kościelnych, a Mahmud Taha Żuk, naczelny imam Rzeczypospolitej, zapoznał zebranych z opinią muzułmańskich związków religijnych.

${ }^{27}$ Kolankowski, Kilka uwag wstęnych, s. 19.

${ }^{28}$ J. Kajta, A. Mrozowicki, Strategie życiowe robotników po 1989 roku-praktyczne i etyczne wyzwania kolekcji danych biograficznych, „Studia Socjologiczne”, 214 (2014) z. 3, s. 246-249.

${ }^{29}$ Zdaniem socjologów do podstawowych zasad służby cywilnej należą wysokie standardy moralne obok apolityczności, stabilności zatrudnienia i profesjonalizmu. R. Sobiech, Analiza badań 
ścią ale również bardziej efektywnie, starając się lepiej wykonywać należące do nich obowiązki. Wiedząc o szczególnym znaczeniu swojej pracy dla obywateli, wykażą się większą aktywnością w pracy zawodowej, starając się znacznie wykroczyć poza przeciętność.

Bardziej rozwinięta świadomość owych zasad i społecznego znaczenia pracy archiwalnej powinna wpłynąć na lepszą obsługę użytkowników i petentów. Otrzymując bardziej szczegółowe informacje o zawartości dokumentacji jej użytkownicy, prowadzący badania naukowe, powinni efektywniej prowadzić poszukiwania źródłowe bezpośrednio wpływające na efekty ich pracy. A to na pewno podniesie poziom badań historycznych, które przecież wpływają na zwiększenie wiedzy o przeszłości oraz pogłębienie świadomości historycznej społeczeństwa. Skorzystać z tego powinni też petenci nie prowadzący badań historycznych zazwyczaj poszukujący bardzo konkretnych informacji o stanie posiadania swoich przodków, pokrewieństwie lub różnych faktach z ich życia lub potrzebujący zaświadczeń i odpisów dokumentów. Otrzymując je, będą mogli z lepszym skutkiem załatwiać ważne dla nich sprawy życiowe przed innymi urzędami czy też sądami, jak również zaspokajać swoje potrzeby związane z poznawaniem dziejów najbliższej rodziny lub biografii ich członków.

Lepsze zaspokajanie potrzeb użytkowników, wynikające z zaangażowania oraz kompetencji archiwalnych i historycznych pracowników archiwów, może nie tylko wzmocnić prestiż archiwistów, ale uczynić z nich również równoprawnych partnerów w badaniach indywidualnych i zespołowych jak również w staraniach o granty badawcze. Natomiast bardziej przyjazna obsługa petentów niebędących badaczami na pewno wzmocni ich zaufanie nie tylko do archiwów ale także państwa i jego administracji, będącej jej ważnym elementem. W polskich urzędach wdraża się już ankietową ocenę ich działalności przez petentów ${ }^{30}$, dlatego archiwa stosując ją mogą tylko zyskać w ich oczach.

Istnienie przejrzystego i społecznie akceptowanego kodeksu etycznego bez wątpienia ułatwi też nauczanie archiwistyki. A jak wiadomo prowadzone jest ono w szerokim zakresie i obejmuje podstawowe kursy dla osób zatrudnionych w archiwach zakładowych, studia podyplomowe przygotowujące absolwentów wyższych uczelni do pracy w archiwach zakładowych, państwowych lub kościelnych, jak również uniwersyteckie studia licencjackie i magisterskie, na których kształci się potencjalnych pracowników archiwów państwowych. Właściwe przygotowanie do zawodu zawierające również określone elementy o charakterze wychowawczym będzie dzięki temu znacznie łatwiejsze. A osoby aplikujące do tego zawodu będą mogły poznać etyczne standardy z nim związane, co powinno przyczynić się do ich przestrzegania w przypadku podjęcia w przyszłości pracy archiwalnej.

społecznych na temat wizerunku stużby cywilnej oraz opracowania rekomendacji dla przysztych badań, Warszawa 2009, s. 27.

${ }^{30}$ Jest to możliwe na podstawie znowelizowanego artykułu 14a Kodeksu postępowania administracyjnego (Dz. U. 2018, poz. 2096). 


\section{Przegląd treści wybranych kodeksów etycznych obowiązujących archiwistów}

W rozważaniach nad zasadami etyki pracy archiwalnej należałoby zacząć od analizy wartości istniejących już normatywów etycznych. Mogą okazać się przydatne i zawierać zasady, które ze względu na swoją wartość warto byłoby wykorzystać przy tworzeniu współczesnego polskiego archiwalnego kodeksu etycznego. Ze względu na brak miejsca w tym opracowaniu można jedynie odwołać się do wybranych normatywów. Analiza treści wszystkich powinna być dokonana w przyszłości, dlatego warto do tego zachęcać. Przed niniejszym artykułem nie postawiono tak ambitnego celu, skupiając się jedynie na próbie wskazania zasad uwzględniających polskie potrzeby.

Kodeks przyjęty w roku 1955 w amerykańskim Archiwum Narodowym w zasadzie trudno uznać za zbiór etyczny, ponieważ w małym stopniu odnosił się do konkretnych wartości. Natomiast zawierał reguły postępowania archiwistów, najbardziej pożądane z praktycznego punktu widzenia, ponieważ stanowiły ich ucieleśnienie. Do nich można zaliczyć nałożony na archiwistów obowiązek zachowania najbardziej wartościowych materiałów archiwalnych i rezygnację z przechowywania dokumentacji mniej wartościowej z powodów czysto finansowych. Archiwistów zobowiązano też, aby przy podejmowaniu decyzji dotyczących selekcji akt nie kierowali się względami ideologicznymi, politycznymi i osobistymi tylko uwzględniali nie tylko aktualne potrzeby, ale dbali o zachowanie materiałów, które mogą być przydatne w przyszłości. Wskazano też na konieczność fizycznego zabezpieczenia dokumentacji powierzonej pieczy archiwistów przed kradzieżą, zniszczeniem, pogorszeniem stanu fizycznego i zniekształceniem. Pracownikom archiwów polecono też, aby dokumentację archiwalną udostępniali zgodnie z interesem społecznym oraz przepisami wewnętrznymi. Nałożono też na nich obowiązek ogłaszania drukiem inwentarzy archiwalnych oraz udzielania konsultacji zainteresowanym użytkownikom.

W dalszych postanowieniach kodeksu zobowiązano archiwistów do grzecznego i rzeczowego odpowiadania na wszelkie pytania petentów, zalecając jednocześnie, aby nie marnowali czasu na udzielanie wyczerpujących odpowiedzi na pytania „lekkomyślne i nierozsądne”. Przestrzeżono też, aby nie piętrzyli przeszkód przed osobami zainteresowanymi wykorzystaniem akt, tylko ułatwiali użytkownikom pracę i oszczędzali ich czas. Archiwistom zakazano rozsiewania plotek o badaniach prowadzonych przez użytkowników, zobowiązując ich jednocześnie do informowania osób zainteresowanych określonym tematem o jego realizacji przez innych badaczy, gdyby taka okoliczność miała miejsce.

Dwie ostatnie zasady regulowały postępowanie archiwistów, niezwiązane z dokumentacją. Należał do nich obowiązek rozwijania zainteresowań historycznych lub innych. Dodano też, że pracownicy archiwów nie powinni czerpać korzyści materialnych z wykorzystywania dokumentacji powierzonej ich pieczy. Uznano też, że ciąży na nich obowiązek ujawniania posiadanych informacji innym archiwistom, które mają znaczenie w pracy archiwalnej oraz przekazywania 
użytkownikom posiadanej wiedzy o układzie i stanie uporządkowania dokumentacji.

Mimo praktycznego charakteru tego kodeksu, zawarte w nim zasady wynikały z wartości przyjętych przez jego autorów jako podstawy działań praktycznych. Zalecane w nim uprzejme postępowanie archiwistów wobec petentów, udzielanie wyczerpujących informacji i powstrzymanie się od czynności, które mogły zostać uznane za utrudniania im pracy, choćby przez wprowadzanie niepotrzebnych wymogów formalnych, miało swoje podłoże aksjologiczne. Wynikało bowiem z szacunku dla osób zwracających się z różnymi prośbami do archiwów i świadomego uznawania realizacji ich potrzeb jako priorytetu w działalności praktycznej.

Bardziej znany niż zbiór amerykański stał się z 1996 roku uchwalony w Pekinie, który zyskał międzynarodowe uznanie. Ponieważ został wprowadzony później niż amerykański, bardziej odpowiadał realiom funkcjonowania współczesnych archiwów. Dlatego należy przyjrzeć się jemu z bliska. Składa się z dziesięciu zasad, można go więc nazwać dekalogiem pekińskim. Zredagowano je zwięźle, co niewątpliwie stanowiło istotną zaletę, ale w rozbudowanych komentarzach umieszczono niekiedy szereg wniosków niezwiązanych bezpośrednio z zasadami, do których miały się odnosić, co zmusza do rozpatrywania ich łącznie i traktowania równorzędnego.

Najbardziej jest to widoczne w komentarzu odnoszącym się do piątej zasady, nakładającej na archiwistów obowiązek ewidencjonowania materiału archiwalnego i potrzeby uzasadniania wszelkich czynności z tym związanych. Wskazano w nim bowiem na potrzebę przechowywania dokumentacji obejmującej pełny cyk1 ich życia oraz współpracy z ich twórcami. Ponadto zalecono też archiwistom, aby dążąc do jej przejęcia starali się zapewnić jego uczciwe warunki, uwzględniające możliwość jej darowizny lub sprzedaży oraz udostępniania. Zasygnalizowano też problem konieczności sporządzania przez pracowników archiwów ewidencji dostępu do dokumentacji, konserwacji oraz innych czynności wykonywanych przez archiwistów, co oznaczało znaczne rozszerzenie pojęcia ewidencji.

Sześć zasad tego dekalogu dotyczyło postępowania z dokumentacją (jej nienaruszalności, poszanowania proweniencji, ochrony autentyczności, dostosowania kryteriów selekcji do zmieniających się potrzeb badawczych, ewidencjonowania jej oraz zapewnienia jak największej dostępności do niej). Pozostałe trzy odnoszą się do cech osobowych archiwistów (respektowanie przez nich przepisów prawa i zachowanie tajemnicy służbowej, unikanie korzyści materialnych z pracy archiwalnej oraz podnoszenie kwalifikacji archiwalnych i dzielenia się wiedzą z użytkownikami). Ostatnia zasada posiada charakter socjalizacyjny i zobowiązuje archiwistów do realizowania ich zadań we współpracy międzynarodowej.

Należy zwrócić uwagę na zakazanie archiwistom czerpania korzyści materialnych $\mathrm{z}$ wykonywanej przez nich pracy ze szkodą dla archiwów, użytkowników i współpracowników. Zabroniono im też kolekcjonowanie dokumentacji, wszelkich form handlowania nią oraz wykonywania czynności, które mogłyby powodować konflikt interesów. Archiwistom nie zabroniono prowadzenia badań naukowych, ale zobowiązano ich do wykorzystywania dokumentacji na zasadach obowiązujących innych użytkowników. Jednocześnie zastrzeżono, aby ich praca 
naukowa nie kolidowała z obowiązkami archiwalnymi. Zakazano im także ujawniania informacji zastrzeżonych oraz ich wykorzystywania w pracy naukowej. Przy wykorzystywaniu materiałów niepublikowanych powinni powiadamiać autorów o tym zamiarze, co może wywoływać wątpliwości, ponieważ w przypadku ich śmierci nie można byłoby tego obowiązku spełnić. Archiwistom zalecono też przeciwstawianie się wszelkim próbom ingerencji z zewnątrz w pracę archiwalną.

Rosyjski kodeks etyczny stanowiący element zasad pracy archiwalnej przyjętych w roku 2002, częściowo nawiązujący do dekalogu pekińskiego, posiada swoją specyfikę, wynikającą z transformacji ustrojowej, jaka dokonała się w tym kraju po upadku Związku Sowieckiego. W jej trakcie starano się zerwać z niechlubnym dziedzictwem ustroju komunistycznego, które odcisnęło swoje negatywne piętno również na archiwach. Znalazło to wyraz w części wstępnej, w której wyraźnie stwierdzono, że pracownicy archiwów przy wykonaniu służbowych obowiązków respektują międzynarodowe normy etyki zawodowej archiwistów, zaakceptowane przez rosyjską społeczność historyków-archiwistów.

Stwierdzono, że głównym obowiązkiem archiwistów jest zagwarantowanie nienaruszalności dokumentacji, przekazanej im do przechowania. Jako miarę ich profesjonalizmu określono obiektywność i bezstronność. Nałożono na nich obowiązek sprzeciwiania się próbom manipulowania dokumentacją w celu ukrycia albo zniekształcenia faktów, co stanowiło reakcję na współdziałanie archiwów z organami bezpieczeństwa oraz ich uczestnictwo w działalności propagandowej narzucanej przez organy partii komunistycznej. Archiwistów zobowiązano też do zachowywania dowodów swoich działań dokumentacyjnych i ich uzasadniania, co także stanowiło próbę zapobieżenia niechlubnemu brakowaniu przechowywanej dokumentacji, po którym często nie zostawało żadnego śladu.

W przeciwieństwie do sowieckiej praktyki polegającej na utrudnianiu dostępu do dokumentacji zarówno badaczom jak i osobom prywatnym przyjęto zasadę zapewniania szerokiego dostępu do dokumentacji i bezstronnej obsługi użytkowników. Na archiwistów nałożono jednak obowiązek dbania o interesy państwa, co można różnie interpretować, w tym także jako bezwzględne podporządkowanie nie tylko racji stanu ale też zarządzeniom władz centralnych i lokalnych ograniczających dostęp do materiałów archiwalnych, które mogą być sprzeczne z innymi zasadami archiwalnymi. Można to uznać jako nawiązanie do dawnych tradycji ścisłego realizowania przez archiwa polityki państwa kosztem interesów obywateli.

Istotne novum stanowiło zobowiązanie archiwistów do zachowania w tajemnicy informacji o życiu prywatnym twórców dokumentacji oraz osób, których ona dotyczyła. Wyraźnie stwierdzono, że w trakcie swojej pracy nie powinni dążyć do uzyskania żadnych korzyści, w tym także finansowych, ani też szkodzić organizacjom, badaczom albo kolegom. Dla uniknięcia kolizji interesów urzędowych z prywatnymi zakazano im kolekcjonowania dokumentacji oraz zawierania umów o charakterze komercyjnym, których byłaby ona przedmiotem.

Za specyficzny ze względu na swoją treść można uznać kodeks obowiązujący członków funkcjonującego w Wielkiej Brytanii i Irlandii Stowarzyszenia Archiwów i Dokumentacji, którego ostatnia wersja została zaaprobowana w roku 2018. 
Zawiera on zasady już wcześniej uznane przez archiwistów za ważne, takie jak integralność dokumentacji, swobodny dostęp do niej oraz selekcja uwzględniająca potrzeby badaczy przeszłości. Pojawiły się w nim także nowe pryncypia. Przede wszystkim stworzono archiwistom możliwość minimalizowania skutków ich działalności oraz podejmowania działań skierowanych przeciwko członkom profesji łamiącym zasady etyczne, polegających na zawiadamianiu o nich pracodawcy lub stowarzyszenia.

Bardzo szeroko opisano możliwe zagrożenia bezstronności archiwistów polegające na wywieraniu na nich presji przez pracodawców czy zwierzchników, uwzględnianiu własnych interesów czy też uprzedzeniach szczególnie utrudniających rzetelną ocenę wartości dokumentacji. Dbałość o obiektywizm w pracy archiwalnej oraz realną ocenę możliwości przechowywania dokumentacji została posunięta tak daleko, że zalecono archiwistom, aby przed przejęciem jakichkolwiek materiałów rozważyli, czy to inna instytucja nie jest lepiej przygotowana do wykonania tej czynności. Ta kontrowersyjna zasada realizowana $\mathrm{w}$ praktyce mogłaby osłabiać rywalizację między placówkami dokumentacyjnymi w przejmowaniu dokumentacji ze szkodą dla efektywności ich pracy.

Sporo uwagi poświęcono ochronie danych osobowych, szczególnie zagwarantowaniu praw do prywatności osób, których dotyczą informacje zawarte w przechowywanej dokumentacji. W kodeksie tym zobowiązano członków stowarzyszenia, aby w miarę możliwości starali się uzyskać zgodę właścicieli dokumentacji do przechowywania danych ich dotyczących, określając wyjątki od tej zasady. Archiwiści i dokumentaliści powinni sobie zdawać sprawę z niebezpieczeństw związanych z ujawnianiem informacji niebezpiecznych dla właścicieli oraz użytkowników. Dlatego polecono wskazywanie osobom wykorzystującym archiwa dokumentacji potencjalnie niebezpiecznej oraz ostrzeganie ich o niebezpieczeństwach związanych z jej analizą. Starano się też zasygnalizować problem ochrony praw właścicieli przekazanych materiałów nawet przewidując możliwości usuwania z nich niewygodnych materiałów, jeżeli nie szkodziłoby to interesowi publicznemu.

Dla ułatwienia porównania wymienionych normatywów etycznych ich najważniejsze elementy treściowe zestawiono w tabeli $\mathrm{nr} 1$.

Tab. 1. Główne elementy treściowe wybranych kodeksów etycznych

\begin{tabular}{|c|c|c|c|c|}
\hline Element treści & $\begin{array}{l}\text { Amerykań- } \\
\text { ski }\end{array}$ & $\begin{array}{l}\text { Międzyna- } \\
\text { rodowy }\end{array}$ & Rosyjski & Brytyjski \\
\hline 1 & 2 & 3 & 4 & 5 \\
\hline \multicolumn{5}{|l|}{ Zasady dotyczące dokumentacji } \\
\hline $\begin{array}{l}\text { Właściwe gromadzenie gwarantujące } \\
\text { szerokie udostępnianie }\end{array}$ & - & pkt 5 & - & pkt $8,11,25$ \\
\hline $\begin{array}{l}\text { Poszukiwanie przed przejęciem bardziej } \\
\text { odpowiednich placówek dokumentacyj- } \\
\text { nych }\end{array}$ & - & - & - & pkt 14 \\
\hline $\begin{array}{l}\text { Sprawdzanie pochodzenia i rejestracja } \\
\text { informacji z tym związanych }\end{array}$ & - & - & - & pkt 8 \\
\hline
\end{tabular}




\begin{tabular}{|c|c|c|c|c|}
\hline 1 & 2 & 3 & 4 & 5 \\
\hline $\begin{array}{l}\text { Dążenie do szukania kompromisowych } \\
\text { rozwiązań w zakresie przechowywania } \\
\text { dokumentacji stanowiącej wspólne dzie- } \\
\text { dzictwo archiwalne }\end{array}$ & - & - & - & pkt 9 \\
\hline $\begin{array}{l}\text { Stosowanie odpowiednich procedur } \\
\text { przechowywania i zabezpieczenia fi- } \\
\text { zycznego dokumentacji }\end{array}$ & pkt 1,3 & pkt 5 & Tak & - \\
\hline $\begin{array}{l}\text { Zachowanie integralności dokumentacji } \\
\text { i zapisów }\end{array}$ & pkt 1,3 & pkt 1 & Tak & pkt $1,11,19$ \\
\hline $\begin{array}{l}\text { Dbałość o zachowanie autentyczności } \\
\text { dokumentacji }\end{array}$ & pkt 3 & - & - & - \\
\hline $\begin{array}{l}\text { Selekcja dokumentacji uwzględniająca } \\
\text { zmieniające się potrzeby użytkowników }\end{array}$ & pkt 2 & pkt 2,4 & - & pkt 3 \\
\hline $\begin{array}{l}\text { Dbałość o reprezentatywność zachowa- } \\
\text { nej dokumentacji }\end{array}$ & - & - & - & pkt 17 \\
\hline $\begin{array}{l}\text { Zastępowanie lub uzupełnianie orygi- } \\
\text { nałów kopiami w innych formatach } \mathrm{z} \\
\text { należytym uwzględnieniem wartości } \\
\text { dokumentacji }\end{array}$ & - & - & - & pkt 21 \\
\hline $\begin{array}{l}\text { Podejmowanie starań o uzyskanie zgo- } \\
\text { dy na przechowywanie danych osobo- } \\
\text { wych zawartych w dokumentacji i ich } \\
\text { udostępnianie zgodnie z interesem osób, } \\
\text { których dotyczą }\end{array}$ & - & pkt 5 & - & pkt 27-32 \\
\hline $\begin{array}{l}\text { Informowanie o czasowym usunięciu } \\
\text { plików dostępnych wcześniej }\end{array}$ & - & - & - & pkt 23 \\
\hline $\begin{array}{l}\text { Zachowanie pochodzenia i pierwotnego } \\
\text { porządku w trakcie porządkowania }\end{array}$ & - & pkt 2,3 & - & pkt 20,22 \\
\hline Ewidencjonowanie dokumentacji & - & pkt 5 & - & - \\
\hline $\begin{array}{l}\text { Ogłaszanie drukiem inwentarzy archi- } \\
\text { walnych }\end{array}$ & pkt 4 & - & - & - \\
\hline $\begin{array}{l}\text { Udostępnianie dokumentacji w jak naj- } \\
\text { szerszym zakresie i prowadzenie ewi- } \\
\text { dencji dostępu do niej }\end{array}$ & pkt 4,5 & $\begin{array}{c}\text { pkt } 4,5, \\
6,7\end{array}$ & - & pkt $2,16,23$ \\
\hline $\begin{array}{l}\text { Udzielanie kompetentnych odpowiedzi } \\
\text { na pytania użytkowników i petentów }\end{array}$ & pkt 5 & - & - & pkt 15 \\
\hline $\begin{array}{l}\text { Upowszechnianie wiedzy o dokumen- } \\
\text { tacji }\end{array}$ & - & - & - & pkt 4 \\
\hline $\begin{array}{l}\text { Ochrona danych zawartych w dokumen- } \\
\text { tacji }\end{array}$ & - & - & - & pkt 10,24 \\
\hline \multicolumn{5}{|l|}{ Zasady dotyczące pracy archiwistów } \\
\hline Przejrzystość podejmowania decyzji & - & - & - & pkt 13,25 \\
\hline Świadomość zagrożeń dla bezstronności & - & - & - & pkt 12 \\
\hline $\begin{array}{l}\text { Doskonalenie umiejętności zawodo- } \\
\text { wych }\end{array}$ & - & pkt 9 & - & pkt 6 \\
\hline $\begin{array}{l}\text { Odpowiedzialność za należyte wykony- } \\
\text { wanie obowiązków przez podwładnych }\end{array}$ & - & pkt 9 & - & pkt 6 \\
\hline
\end{tabular}




\begin{tabular}{|c|c|c|c|c|}
\hline 1 & 2 & 3 & 4 & 5 \\
\hline $\begin{array}{l}\text { Minimalizowanie negatywnych skut- } \\
\text { ków pracy }\end{array}$ & - & - & - & pkt 5 \\
\hline $\begin{array}{l}\text { Unikanie konfliktów i sprzeczności in- } \\
\text { teresów }\end{array}$ & - & pkt 10 & - & pkt 13 \\
\hline $\begin{array}{l}\text { Dzielenie się wiedzą o dokumentacji z } \\
\text { innymi archiwistami }\end{array}$ & pkt 7 & - & - & - \\
\hline $\begin{array}{l}\text { Informowanie użytkowników o realizo- } \\
\text { wanych tematach dla zapobieżenia du- } \\
\text { blowaniu badań }\end{array}$ & pkt 5 & - & - & - \\
\hline $\begin{array}{l}\text { Współpraca międzynarodowa w wyko- } \\
\text { rzystywaniu dokumentacji }\end{array}$ & - & pkt 10 & - & - \\
\hline $\begin{array}{l}\text { Współpraca z przedstawicielami innych } \\
\text { zawodów }\end{array}$ & - & pkt 10 & - & pkt 4 \\
\hline $\begin{array}{l}\text { Zapewnienie osobom, których dotyczy } \\
\text { dokumentacja, prawa do zachowania w } \\
\text { tajemnicy szczegółów ich życia }\end{array}$ & pkt 5 & - & tak & pkt 24,26 \\
\hline $\begin{array}{l}\text { Dokumentowanie wykonanych czynno- } \\
\text { ści archiwalnych i ich uzasadnianie }\end{array}$ & - & - & tak & - \\
\hline $\begin{array}{l}\text { Obowiązek rozwijania zainteresowań } \\
\text { historycznych lub innych }\end{array}$ & pkt 6 & - & - & - \\
\hline $\begin{array}{l}\text { Możliwość wykorzystywania dokumen- } \\
\text { tacji do własnych badań }\end{array}$ & - & - & - & pkt 18 \\
\hline $\begin{array}{l}\text { Unikanie kolizji między własnymi ba- } \\
\text { daniami naukowymi a pracą archiwalną }\end{array}$ & - & pkt 8 & - & - \\
\hline $\begin{array}{l}\text { Przeciwstawianie się zewnętrznym in- } \\
\text { gerencjom w pracę archiwalną }\end{array}$ & - & pkt 1,8 & - & - \\
\hline $\begin{array}{l}\text { Rezygnacja } \mathrm{z} \text { kolekcjonowania doku- } \\
\text { mentacji lub handlu nią }\end{array}$ & - & pkt 8 & tak & - \\
\hline $\begin{array}{l}\text { Zachowanie tajemnicy instytucji i osób } \\
\text { prywatnych }\end{array}$ & & pkt 7,8 & tak & \\
\hline $\begin{array}{l}\text { Uwzględnianie zasad bezpieczeństwa } \\
\text { narodowego }\end{array}$ & - & - & tak & - \\
\hline $\begin{array}{l}\text { Zakaz uzyskiwania korzyści material- } \\
\text { nych }\end{array}$ & pkt 6 & pkt 8 & tak & - \\
\hline $\begin{array}{l}\text { Wskazywanie niewłaściwego zachowa- } \\
\text { nia osobom za to odpowiedzialnym }\end{array}$ & - & - & - & pkt 7 \\
\hline \multicolumn{5}{|l|}{ Cechy konieczne w pracy archiwistów } \\
\hline Zawodowa integralność & - & pkt 8 & - & - \\
\hline Obiektywizm & - & pkt 1,8 & tak & - \\
\hline Bezstronność & - & pkt 1,8 & tak & pkt 12 \\
\hline Równość & - & - & - & pkt 11 \\
\hline
\end{tabular}

Z przedstawionego porównania wynika kilka istotnych wniosków. Stopniowo następuje uszczegółowienie zbiorów zasad etycznych, czego dowodzi wzrost ich objętości. Wyjątkiem są tutaj zasady rosyjskie, pod względem ilościowym 
odbiegają od zbiorów wprowadzonych w państwach zachodnich. Uwzględniając jednak fakt, że wcześniej w pracy archiwalnej w ZSRS i Federacji Rosyjskiej nie obowiązywały żadne normy etyczne, to sformułowanie ich po kilkunastu latach od transformacji ustrojowej stanowiło zarówno postęp jakościowy jak i ilościowy. I można przypuszczać, że tendencja ta będzie rozwijała się w przyszłości zarówno w Rosji jak i na świecie.

W świadomości autorów tworzących wymienione zbiory zasad dokonał się swoisty odwrót od historii. W kodeksie amerykańskim zobowiązano archiwistów do prowadzenia badań historycznych lub innych, co stanowiło dowód uznawania potrzeby ich łączenia z pracą archiwalną. W pozostałych normatywach etycznych na ten temat nie ma już żadnych wzmianek. Za słuszne można uznać skłanianie archiwistów do doskonalenia umiejętności zawodowych, ponieważ większy profesjonalizm na pewno wpływa na zwiększenie efektów ich pracy, co w konsekwencji powinno spowodować zwiększenie prestiżu archiwistów w świecie naukowym.

Pozytywnie należy uznać zobowiązanie archiwistów do przeciwstawiania się wszelkim naciskom na ich pracę płynącą z zewnątrz, co zostało zapisane w kodeksie międzynarodowym. Po doświadczeniach funkcjonowania archiwów w państwach totalitarnych takich jak niemiecka III Rzesza czy Związek Sowiecki, nie ma wątpliwości, że naciski polityczne czy też nawet włączenie archiwów do systemu politycznej propagandy stanowi dla nich wielkie zagrożenie, uniemożliwiając im wypełnianie podstawowych funkcji związanych z przejmowaniem, opracowaniem i udostępnianiem materiałów archiwalnych i przez to obniżając ich prestiż w społeczeństwie.

Coraz więcej uwagi przywiązuje się do profesjonalizacji zawodu archiwisty, traktując go jednak tak jak inne i nie przypisując mu szczególnych cech odróżniających go od innych profesji. Pociąga to za sobą również zakaz uzyskiwania w pracy archiwalnej jakichkolwiek korzyści materialnych i zmusza też do wskazywania niewłaściwego postępowania archiwistom w każdym tego typu przypadku, a nawet pociąga za sobą odpowiedzialność za niewłaściwe postępowanie podwładnych. W tym kontekście zrozumiałe jest zakazywanie archiwistom kolekcjonowania dokumentacji oraz wszelkich form handlowego obrotu nią, pociągającego za sobą finansowy zysk.

W kontekście profesjonalizacji obowiązek unikania kolizji między własnymi badaniami, a pracą archiwalną można uznać za ogólnie słuszny. Prowadzenie badań przez archiwistów ze szkodą dla ich obowiązków archiwalnych byłoby ze wszech miar niewskazane, ponieważ obniżałoby efekty pracy archiwów, w których są zatrudnieni. $Z$ drugiej strony byłoby uzasadnione, aby pracy naukowej archiwistów nie traktowano jako jedynie sprawy indywidualnej samych zainteresowanych jej prowadzeniem, tylko starano się włączyć ją do przedsięwzięć archiwalnych, oczywiście, jeżeli to byłoby możliwe i z zachowaniem odpowiednich proporcji. Wspieranie pracy naukowej archiwistów należy traktować jako zadanie pierwszoplanowe, ponieważ wzmacnia ona potencjał intelektualny archiwów. 


\section{Specyficzna rola polskich archiwów}

Stwierdzono już, że kodeks uchwalony w Pekinie nie odpowiada w pełni polskim warunkom i związanym z nimi potrzebom, dlatego należy wyjaśnić, na czym polega odmienność polskiego państwa oraz funkcjonujących w nich archiwów. Bowiem na pierwszy rzut oka ich organizacja, funkcje oraz działalność nie wykazują poważniejszych odmienności. Aktywnie współpracują z innymi placówkami dokumentacyjnymi w kraju i za granicą, a polscy archiwiści biorą udział w obradach Międzynarodowej Rady Archiwalnej, stosują międzynarodowe standardy archiwalne oraz uczestniczą w różnych programach tworzonych pod egidą UNESCO.

Specyfika działania polskich archiwów wynika z tragicznej przeszłości naszego kraju związanej z rozbiorami, dramatem II wojny światowej oraz komunistycznym zniewoleniem trwającym aż do roku 1989, a więc przez 45 lat. Szczególnie zostały doświadczone w okresie II wojny światowej, kiedy bezpowrotnie straciły dużą część swojego zasobu. W tym okresie archiwa poniosły wielkie straty z powodu wywożenia akt do Niemiec oraz planowego niszczenia lub grabieży dóbr kultury znajdujących się wtedy w Warszawie przez niemieckiego okupanta w czasie Powstania Warszawskiego ${ }^{31}$. Duża cześć dokumentacji archiwalnej razem z innymi zabytkami trafiła w ręce sowieckiego agresora ${ }^{32} \mathrm{i}$ w przeważającej mierze pozostała już na terenach ZSRS do końca jego istnienia. Potem znalazła się w państwach powstałych po rozpadzie tego mocarstwa (Rosji, Białorusi, Ukrainy i Litwy).

Obecnie w Rosji nie wszystkie materiały wywiezione z Polski są dostępne dla naszych badaczy, a te, które się udostępnia, można wykorzystywać z reguły w dużo gorszych warunkach niż w polskich archiwach. W archiwach krajów powstałych po rozpadzie ZSRS (z wyjątkiem Litwy) nie dopuszcza się do bezpłatnego sporządzania fotokopii, pozostawiając jedynie możliwość ich skanowania za wysoką opłatą. Zazwyczaj nie ma też możliwości wykorzystywania skanów dokumentacji archiwalnej za pośrednictwem Internetu na taką skalę jak w Polsce. Do tego należy też dodać koszty związane z podróżami i pobytem obciążające badaczy przeprowadzających kwerendy za granicą.

W okresie powojennym, aż do końca istnienia PRL duża część cennych materiałów znajdujących się $\mathrm{w}$ archiwach resortu spraw wewnętrznych oraz partyjnych (PZPR) nie była dostępna dla historyków niezatrudnionych w aparacie bezpieczeństwa oraz nienależących do partii rządzącej. $Z$ tego powodu nie było możliwe prowadzenie rzetelnych badań nad takimi zagadnieniami jak dzieje partii komunistycznej w okresie międzywojennym i okupacji niemieckiej oraz działalność zbrojnego podziemia antykomunistycznego w Polsce po zakończeniu II wojny światowej.

${ }^{31}$ D. Matelski, Problem restytucji polskich dóbr kultury od czasów nowożytnych do wspótczesnych. Archiwa - księgozbiory - dzieta sztuki-pomniki, Poznań 2013, s. 210-227.

${ }^{32}$ Tamże, s. 234-241. 
System oficjalnej propagandy zakłamywał dzieje Polski, tworząc fałszywych bohaterów ${ }^{33}$, niezgodnie z faktami gloryfikując działalność lewicowych i komunistycznych partii i ugrupowań politycznych, bez uzasadnienia wypaczając obraz innych, deformując obraz wojska i marynarki okresu II RP, rządu emigracyjnego ${ }^{34}$ oraz przemilczając faktyczne osiągnięcia wybranych osób i środowisk. Także w systemie nauczania zniekształcano ze powodów politycznych obraz wielu zjawisk i procesów ${ }^{35}$, co spowodowało negatywne zmiany w świadomości naszych obywateli. $Z$ drugiej strony te urzędowe niejako deformacje wzmacniały dążenie części obywateli do poznawania przeszłości własnego kraju w sposób nieskrępowany bez jakichkolwiek ograniczeń ideologicznych, politycznych czy też rzeczowych, czego dowodem stały się bezdebitowe publikacje drugiego obiegu odnoszące się do zagadnień historycznych ${ }^{36}$, które jednak docierały do ograniczonego kręgu osób.

Od wypaczeń nie była też wolna nauka historyczna, ponieważ część badaczy, szczególnie zajmujących się historią najnowszą uległa politycznym naciskom i brała udział $\mathrm{w}$ działaniach o charakterze bardziej propagandowym niż naukowym $^{37}$. Zdarzało się też fałszowanie badań z powodów czysto politycznych ${ }^{38}$.

${ }^{33}$ Oprócz takich „bohaterów” jak wódz rewolucji Lenin, czy przywódcy partyjni w rodzaju W. Gomułki oraz dowódców wojskowych (K. Rokossowski czy M. Rola-Żymierski) propagowano kult szeregowych członków ruchu komunistycznego. Tak było z postacią Naftalego Botwina, członka KPZU, który został z wyroku sądu doraźnego rozstrzelany za zabicie we Lwowie Józefa Cechnowskiego, tajnego funkcjonariusza policji politycznej, który skutecznie szkodził partii komunistycznej. Nazwiskiem Botwina nazwano ulice w wielu polskich miastach, a w Ząbkowicach Śląskich i Pieszycach dalej jest ich patronem, mimo upływu 30 lat od rozpoczęcia transformacji ustrojowej. M. Piotrowska, Sprawa zabójstwa Józefa Cechnowskiego w roku 1925 a rola Stanisława Radkiewicza, „Zeszyty Naukowe UJ Prace Historyczne”, 144 (2017) z. 4, s. 645-667.

${ }^{34} \mathrm{~B}$. Zalewski, Rola historii polskiej marynarki wojennej $i$ historii wojen morskich $w$ ksztatceniu oficerów, w: Kształtowanie świadomości historycznej żolnierzy, pod red. J. Karwata, Warszawa -Poznań, 2002, s. 84-85.

${ }^{35} \mathrm{Z}$ licznych prac dotyczących tego problemu można wymienić: J. Wojdon, Propaganda polityczna w podręcznikach dla szkót podstawowych 1944-1989, Toruń 2001, s. 200-229; H. Składanowski, Stosunki polsko-sowieckie w programach nauczania i podręcznikach historii w szkole powszechnej (podstawowej) w Polsce w latach 1932-1956, Toruń 2004, s. 164-166, 266-275; Z. Osiński, Nauczanie historii w szkołach podstawowych w Polsce w latach 1944-1989. Uwarunkowania organizacyjne i ideologiczno-polityczne, Lublin 2010, s. 144, 147-148, 153, 158; M. Żaryn, Polityka historyczna w edukacji PRL, w: Polityka czy propaganda. PRL wobec historii, red. P. Skibiński, T. Wiścicki, M. Wysocki, Warszawa 2009, s. 121, 125-126, 134-135, 139-142.

${ }^{36}$ M. Mikołajczyk, Jak sie pisało o historii... Problemy polityczne powojennej historii Polski w publikacjach drugiego obiegu w latach siedemdziesiątych i osiemdziesiatych, Kraków 1998, s. 146-188.

${ }^{37}$ Przykładowo tak było w czasie kampanii propagandowej przeciw Kościołowi po słynnym liście biskupów polskich do niemieckich w 1965 r. T. P. Rutkowski, Nauki historyczne w Polsce 1944-1970. Zagadnienia polityczne i organizacyjne, Warszawa 2007, s. 440-444.

${ }^{38}$ Do takich problemów należała między innymi historia Polskiej Partii Robotniczej (PPR). P. Gontarczyk, Polska Partia Robotnicza. Droga do władzy (1941-1944), Warszawa 2006, s. 7-8; tenże, Poprawianie historii PPR. Metody fatszowania źródel historycznych w pierwszej edycji dokumentów PPR, „Biuletyn Instytutu Pamięci Narodowej”, nr 1-2, 2005, s. 33-49. 
$\mathrm{Z}$ tego powodu istnieje wielka potrzeba odkłamania wielu istotnych fragmentów naszych dziejów, a nawet odkrywania ich na nowo. Dlatego powołano do tego w roku 1999 Instytut Pamięci Narodowej, który obecnie prowadzi się zakrojone na szeroką skalę badania nad pierwszymi latami powojennymi oraz okresem $\mathrm{PRL}^{39}$ wspomagany przez historyków zatrudnionych w uniwersytetach i instytutach naukowych, a także badaczy regionalnych.

Po zmianie ustrojowej i pozbyciu się totalitarnych pozostałości, ze względu na istotne uszczuplenie zasobu oraz faktyczną blokadę poszukiwań źródłowych do wielu istotnych tematów, polskie archiwa były niejako zobowiązane do ułatwienia wszystkim badaczom prowadzenia kwerend i gromadzenia potrzebnych materiałów. I z tego zadania wywiązały się dobrze, znacznie lepiej niż to zrobiono w sąsiednich krajach. Umożliwiły bowiem fotokopiowanie potrzebnych materiałów własnym sprzętem, co można uznać za wydarzenie bez precedensu w naszej praktyce udostępniania, co spowodowało wprowadzenie podobnych rozwiązań w IPN oraz niektórych bibliotekach naukowych. Archiwa sukcesywnie zamieszczają coraz więcej skanów na portalu www.szukajwarchiwach.gov.pl, który cieszy się coraz większym zainteresowaniem badaczy. W tej chwili udostępniono już 38 milionów skanów dokumentacji archiwalnej oraz 13 milionów opisów materiałów archiwalnych, co jest ogromną liczbą.

Należy pamiętać, że Polska jest krajem, którego znacząca część obywateli nie jest obojętna wobec spraw jego przeszłości ${ }^{40}$, a także przejawia zainteresowanie dziejami regionu, w którym mieszkają ${ }^{41}$. Przeszłość własnego państwa ceni też młodzież $\dot{ }^{42}$, co w dużej mierze zostało spowodowane jej wielowiekowym drama-

${ }^{39}$ Bez taryfy ulgowej. Dorobek naukowy i edukacyjny Instytutu Pamięci Narodowej 2000-2010, red. A. Czyżewski, S. M. Nowinowski, R. Stobiecki, J. Żelazko, Warszawa 2012; O zadaniach IPN na tym polu pisał Ł. Kamiński, Czy potrzebna jest instytucja pamięci? w: Dziennikarz - między prawda a kłamstwem. VII Ogólnopolska Konferencja Pamięć i tożsamość Polaków - dziś, Łódź 2013, s. 30-32.

${ }^{40} \mathrm{Z}$ analiz przeprowadzonych w roku 2015 przez Ośrodek Badania Opinii Publicznej (TNS OBOP) wynika, że połowa respondentów określiła swoje zainteresowanie historią jako średnie, a jedna czwarta oceniła je jako bardzo duże lub duże. A. Wysocki, Stosunek społeczeństwa polskiego do przeszłości a tożsamość narodowa. Analiza badań sondażowych, „Annales UMCS”, sec. I, 43 (2018) nr 1, s. 114. Charakterystyczne, że wśród motywów sztuki artystów nieprofesjonalnych dominują tematy historyczne. A. Jarysz, Dzieło sztuki na granicy przeszłości i przyszłości. Historia i patriotyzm w sztuce nieprofesjonalnej, „Sprawy Narodowościowe Seria nowa”, 47 (2015) s. 106114.

${ }^{41} \mathrm{O}$ roli historii w świadomości Polaków świadczy wysoki stopień akceptacji dla obchodzenia różnego rodzaju rocznic, „niezależnie od ich polskości czy niemieckości” przez 91\% polskich studentów ze Szczecina, Zielonej Góry i Wrocławia, przy jednoczesnym przeświadczeniu znacznej większości z nich (powyżej 80\%), że pielęgnowanie miejscowego dziedzictwa jest zgodne $\mathrm{z}$ interesem narodu niemieckiego. Z. Mazur, K. Wawruch, Niemieckie komponenty $w$ świadomości historycznej studentów Ziem Zachodnich i Pótnocnych, „Zeszyty Instytutu Zachodniego”, 26 (2002) s. 21-23.

${ }^{42}$ Badania wskazują, że ponad 80\% młodzieży gimnazjalnej i licealnej warszawskiej uznała, że historia jest bardzo potrzebna lub dość potrzebna. Ł. Michalski, Świadomość historyczna uczniów szkót ponadpodstawowych w aglomeracji warszawskiej. Raport z badań, Warszawa 2015, s. 77-79. 
tyzmem. Przeszłość w formie świadomości historycznej czy pamięci zbiorowej stanowi ważny czynnik kształtujący tożsamość narodową nie tylko w Polsce ${ }^{43}$, dlatego jej upowszechnianie stanowi zarówno obowiązek państwa jak i powinność obywateli. Archiwiści wspomagając historyków w ich badaniach, pośrednio przyczyniają się do wzmacniania świadomości historycznej Polaków. Natomiast prowadząc badania nad przeszłością czynią to bezpośrednio, chociaż jak wiadomo, nie należy to do ich głównych zadań. Jest to szczególnie istotne obecnie, kiedy dokonuje się stopniowe osłabianie spoistości narodowej, choćby przez próby tworzenia tożsamości europejskiej, opartej o wartości sprzeczne $\mathrm{z}$ dotychczasową tradycją ${ }^{44}$ W tym kontekście zwykła praca archiwistów skupiona na dokumentacji i z pozoru pozbawiona wartości ideowych nabiera znaczenia działalności o charakterze niemal fundamentalnym dla tożsamości obywateli i państwa.

Taką rolę pełnią urządzane $\mathrm{w}$ archiwach pokazy dokumentacji w formie tradycyjnej czy też wirtualnej, prelekcje czy też odczyty jak również wydawnictwa źródłowe odnoszące się do kluczowych momentów w dziejach Polski. Są nimi niewątpliwie zrywy niepodległościowe w XIX wieku, wojna polsko-bolszewicką, agresja niemiecką i sowiecka w roku 1939, martyrologia ludności polskiej w okresie ostatniej wojny światowej, ruch oporu walczący z obu okupantami, działalność zbrojnego podziemia antykomunistycznego w latach powojennych, a później opór społeczeństwa polskiego wobec narzuconej mu władzy totalitarnej. Pokazują one chwalebne cechy Polaków ich upór, odwagę, ofiarność, umiłowanie wolności, narażanie własnego życia dla dobra społeczeństwa, które powinny stanowić wzór dla naszej młodzieży, a dorosłym żyjącym obecnie przypominać wartości przez wielu z nich zapomniane ${ }^{45}$.

Archiwa wcale nie muszą zachowywać wstrzemięźliwości w odniesieniu do kwestii aksjologicznych. Mogą bowiem prezentować dokumentację zawierającą treści pod tym względem neutralną i odzwierciedlającą różne wydarzenia czy też procesy społeczne i nie skłaniającej odbiorców do zajęcia określonego stanowiska. Ale lepiej byłoby, gdyby w miarę możliwości przy okazji organizacji wystaw, wydawania okolicznościowych albumów lub zbiorów dokumentacji propagowały również wartości patriotyczne ukazując pozytywne postawy rodaków świadczące o ich oddaniu dla sprawy narodowej i gotowości do poniesienia ofiar. W ten sposób mogłyby oddziaływać na sposób myślenia użytkowników i upowszechniając wśród szacunek dla wszelkich działań służących niepodległości oraz postaw propaństwowych. Oczywiście, nie chodzi tutaj o propagandę czy też manipulację,

${ }^{43}$ Dobitnie stwierdził to P. Ścigaj, Tożsamość narodowa. Zarys problematyki, Kraków 2012, s. 179-181. Potwierdzają to niektóre badania socjologiczne. Według analiz EURONAT wspólna historia i wspólne losy były ważne dla $64 \%$ polskich respondentów uczestniczących w badaniu. Wyższe wskaźniki osiągnięto na Węgrzech (65\%) oraz w Grecji (79\%). J. Górniak, Tożsamość narodowa a tożsamość polska, w: Tożsamość europejska a tożsamość polska, Warszawa 2005, s. 24-25.

${ }^{44}$ M. Sitek, Tożsamość narodowa (europejska) a obywatelstwo Unii Europejskiej, „Journal of Modern Science", 4 (27), 2015, s. 122-123. (http://www.jomswsge.com/Tozsamosc-narodowa-europejska-na-obywatelstwo-Unii-Europejskiej,80584,0,1.html dostęp: 2019-07-27)

${ }^{45}$ T. Płużański, Pokolenie AK i Żołnierzy Niezłomnych wzorcem dla dzisiejszej młodzieży, w: Dziennikarz - między prawda a kłamstwem, s. 126-128. 
których nie można pogodzić z uczciwą pracą archiwalną, tylko o promowanie wymienionych wartości dzięki prezentacji źródeł archiwalnych i ich rzetelnej interpretacji.

Dobrym przykładem właściwego działania stanowi album upamiętniający powstanie styczniowe, wydany kilka lat temu przez lubelskie Archiwum Państwo$\mathrm{we}^{46}$. Obok dokumentacji ukazującej działania, zjawiska czy wydarzenia związane z przebiegiem walki zbrojnej oraz jej efektami zarówno militarnymi jak i politycznymi oraz działania władz carskich, zmierzające do ograniczania rozmiarów powstania, znalazły się w nim świadectwa postaw patriotycznych mało znanych mieszkańców guberni lubelskiej, które ukazują mniej spektakularne formy oporu wobec zaborcy. Jednym z nich jest kopia anonimu z roku 1861 wzywającego mieszkańców Lublina do zaprzestania zabaw w czasie nasilenia nastrojów patriotycznych ${ }^{47}$. Podobne świadectwo stanowi raport naczelnika powiatu zamojskiego z roku 1962, zawierający informację o aresztowaniu i osadzeniu w twierdzy zamojskiej dwóch niższych urzędników miejskich pochodzących z Biłgoraja i Zamościa, których oskarżono o śpiewanie zabronionych pieśni ${ }^{48}$.

\section{Potrzeba wprowadzenia nowych zasad w kodeksie etycznym polskich archiwistów}

Słuszność większości zasad kodeksu przyjętego w Pekinie wydaje się oczywista, ponieważ w specyficznych polskich warunkach nie budzą zastrzeżeń. Jednak trudno oczekiwać, aby jeden zbiór zasad zaspokajał potrzeby obywateli wszystkich krajów, geograficznie często od siebie odległych, posiadających swoją odmienną historię, a także należących do różnych kręgów kulturowych. Z tego względu kodeks etyczny uchwalony przez reprezentatywne gremium archiwalne powinien być nie tyle tworem ostatecznym, niepodlegającym żadnym zmianom, ale raczej produktem wyjściowym, umożliwiającym opracowanie zasad etycznych dostosowanym do potrzeb poszczególnych państw.

Podstawowy zarzut, jaki należy zgłosić z polskiego punktu widzenia pod adresem kodeksu pekińskiego wynika $\mathrm{z}$ traktowania $\mathrm{w}$ nim pracy archiwalnej jak zwykłej czynności o charakterze profesjonalnym. A tymczasem polscy archiwiści słusznie twierdzili, że ich zawodowy wysiłek ma charakter misyjny, chociaż w niektórych okresach miał on charakter wąski i ściśle ukierunkowany ${ }^{49}$. Biorąc pod uwagę niewątpliwie szczególny charakter pracy archiwalnej można uznać ją za służbę na rzecz polskiej nauki, kultury, państwa i społeczeństwa. Mianem służby określa się niezbędność pracy dla innych ludzi lub działanie na rzecz jakiejś idei czy też poświęcenie określonej sprawie ${ }^{50}$. Nie ma wątpliwości, że zadania

${ }^{46}$ Dokumenty powstania styczniowego: wydarzenia - ludzie - tradycja, red. P. Dymmel, R. Hordyjewski, Lublin 2013.

${ }^{47}$ Tamże, s. 11.

${ }^{48}$ Tamże, s. 12.

49 J. Skowronek, Misja archiwisty i problemy rewindykacji archiwaliów - Specyfika Europy Środkowo-Wschodniej XIX i XX w., „Archeion”, 94 (1995) s. 9.

${ }^{50}$ Stownik języka polskiego PWN, red. M. Szymczak, t. 3, Warszawa 1998, s. 244. 
archiwistów mieszczą się w tym pojęciu, ponieważ polegają na zachowaniu dokumentacji, aby mogła służyć zarówno do poznawania przeszłości, a także stanowiła składnik dziedzictwa kulturowego. Pracownicy archiwów są strażnikami dokumentacji i w pewnym sensie można ich porównać do żołnierzy stojących na straży niepodległości państwa, policjantów niezbędnych do zapewnienia bezpieczeństwa obywateli, czy lekarzy, powołanych do troski o nasze zdrowie.

I nie chodzi tutaj o dodatkowe uzasadnienie przynależności archiwistów do korpusu służby cywilnej, co dokonano na podstawie rozporządzenia Prezesa Rady Ministrów z 29 stycznia 2016 roku $^{51}$. Ustawa o służbie cywilnej z 21 listopada 2008 r. zobowiązała urzędników do respektowania określonych wartości takich jak: przestrzeganie konstytucji i przepisów prawa, ochrona interesów państwa i obywatela, racjonalne gospodarowanie środkami publicznymi, rzetelne, bezstronne, sprawne i terminowe wykonywanie obowiązków, dochowywanie tajemnicy służbowej, rozwijania wiedzy zawodowej oraz godnego zachowania w służbie i poza nią ${ }^{52}$. Mają one charakter ogólny i dotyczą wszystkich urzędników, dlatego nie mogą wystarczyć w pracy archiwalnej, która przecież jak już wskazano, posiada swoją specyfikę.

Misyjny charakter pracy archiwalnej można wyrazić w odrębnym punkcie, akcentującym tę szczególną cechę, którą pomijano w opisywanych kodeksach etycznych:

Praca w archiwach państwowych ze względu na wielką wartość przechowywanej w nich dokumentacji oraz znaczenie jej udostępniania dla celów naukowych, administracyjnych i prywatnych jest służbą na rzecz państwa oraz jego obywateli, dlatego wymaga od zatrudnionych w niej osób szczególnego zaangażowania i odpowiedzialności.

Także piąty punkt normatywu etycznego przyjętego w Pekinie, wskazujący na potrzebę ewidencjonowania dokumentacji, wydaje się nie bardzo dostosowany do polskich warunków ze względu na jego zbytnią ogólnikowość. W komentarzu do tej zasady interpretowano treść tej zasady, ale nie uzasadniono potrzeby jej istnienia. Zamiast tego zwrócono uwagę na inne kwestie, o czym już wspomniano. Nasuwa to wniosek, że twórcy nie do końca przemyśleli treść tego fragmentu kodeksu. Jednak pomijając nieadekwatny komentarz i uwzględniając bardzo zwięzłą treść wymienionej zasady można uznać, że samo stwierdzenie potrzeby ewidencjonowania dokumentacji nie może wystarczyć w polskich archiwach.

Literalne rozumienie tej zasady prowadziłoby do informacyjnego minimalizmu, polegającego na zadowalaniu się tworzeniem w polskich archiwach pomocy ewidencyjnych niskiej jakości, ułatwiających co prawda udostępnianie jednostek archiwalnych wchodzących w skład zespołów archiwalnych, ale zawierających jedynie minimum informacji o zawartości akt. W naszych archiwach takimi pomocami są spisy zdawczo-odbiorcze, sporządzane w trybie administracyjnym przez osoby o niskich kwalifikacjach profesjonalnych. Zamiast tego należałoby zobowiązywać archiwa do stałego ulepszania swojego aparatu informacyjnego,

\footnotetext{
${ }^{51}$ Dz. U. z 2016 r. poz. 125.

${ }^{52}$ Dz. U. z 2008 r. nr 227, poz. 1505 , art. 76.
} 
pozostawiając im inicjatywę w tym zakresie i ufając, że będą dążyć do opracowywania coraz lepszych inwentarzy do zespołów archiwalnych o wysokiej wartości informacyjnej oraz cieszących się dużym zainteresowaniem ze strony historyków. treść:

Zasada wyrażająca ten pogląd mogłaby otrzymać następującą bardzo prostą

Archiwiści powinni dążyć do udoskonalania pomocy informacyjnych, szcze-

gólnie w odniesieniu do zespołów najcenniejszych i najczęściej wykorzystywanych przez użytkowników.

Oczywiście nie może być ona interpretowana jako stały obowiązek, który powinien być realizowany bez względu na okoliczności ze szkodą dla innych zadań archiwum. Chodzi tu jedynie o wskazanie archiwistom istotnego zadania, którego realizacja na pewno ułatwić prowadzenie kwerend archiwalnych przez użytkowników.

W kodeksie przyjętym w Pekinie pominięto problem zbiorów dokumentacji pozostającej w rękach prywatnych, co nie dziwi, ponieważ w krajach zachodnich demokracji europejskich oraz w Stanach Zjednoczonych istnieją archiwa prywatne, społeczne oraz municypalne. Stanowią one odrębny podmiot, mają zagwarantowane podstawy materialne swojej działalności i perspektywę dalszego funkcjonowania, dlatego posiadają pozycję równorzędną w stosunku do archiwów państwowych, które nie muszą zajmować się dokumentację proweniencji prywatnej.

Zupełnie inna sytuacja jest w naszym kraju, gdzie tego rodzaju instytucjonalnych archiwów prywatnych nie ma. Mało tego, w rękach obywateli znajdują się wartościowe materiały w postaci dokumentacji aktowej, listów czy też korespondencji oraz wspomnień pozostałych po osobach prywatnych, rodzinach czy też rodach. Istnieją w postaci zbiorów, znajdujących się w posiadaniu osób prywatnych i z tego powodu ich przyszłość nie jest rozstrzygnięta ani pewna. Po śmierci dotychczasowych właścicieli zbiorom tym grozi niebezpieczeństwo rozproszenia, a nawet zniszczenia. Dopuszczenie do tego spowodowałoby niepowetowane straty dla nauki i kultury, do których w żadnym przypadku nie można dopuścić, ponieważ Polska utraciła zbyt wiele dóbr kultury w czasie ostatniej wojny, aby sytuacja tego rodzaju mogła się powtórzyć.

$\mathrm{Z}$ tego względu archiwa państwowe muszą pamiętać o istnieniu takiej dokumentacji i podejmować wszelkie działania zmierzające do przejęcia wspomnianych materiałów, jeśli tylko pojawi się niebezpieczeństwo ich zniszczenia, oczywiście za zgodą dotychczasowych posiadaczy, w następstwie darowizny czy też depozytu. Natomiast, gdyby to nie było możliwe, to archiwa powinny dążyć do skanowania prywatnych zbiorów dokumentacji na podstawie umów zawartych z ich właścicielami, zastrzegając w nich możliwość udostępniania formie cyfrowej w przyszłości, na ściśle określonych warunkach. Chodzi bowiem o zapewnienie możliwości wykorzystywania ich przez wszystkie zainteresowane osoby.

Odpowiedni fragment zbioru zasad mógłby mieć następującą treść:

Archiwa są zobowiązane do wykazywania stałej troski o cenne materiały archiwalne, znajdujące się w rękach prywatnych, dążąc do ich przejęcia, jeśliby groziłoby im niebezpieczeństwo. Gdyby okazało się to niemożliwe, należałoby od nich oczekiwać, aby wykonały za zgodą właścicieli na swój koszt 
kopie cyfrowe dokumentacji znajdującej się w ich posiadaniu i udostępniały w przyszłości na ustalonych z nimi zasadach.

Użyte wyżej określenie „troska” należy rozumieć jako gotowość do podejmowania działań na rzecz ochrony cennej dokumentacji pozostającej własnością osób prywatnych. Ta zasada ma na celu zobowiązanie pracowników archiwów państwowych do rozszerzenia pola oddziaływania, uzasadnionego ważnym celem społecznym. To już stopniowo następuje, czego dowodem jest umieszczanie na stronach internetowych poszczególnych placówek informacji dotyczących archiwów rodzinnych a nawet tworzenie stałych punktów informacyjnych, jak to uczyniły między innymi archiwa białostockie ${ }^{53}$ i rzeszowskie ${ }^{54}$. Inne wydały albumy prezentujące najciekawsze materiały pozyskane od osób prywatnych ${ }^{55}$. Sformułowanie wyżej opisanej zasady wynikło także z działań podejmowanych już wcześniej przez archiwa, a nie stanowiło jedynie próby narzucania im dodatkowego zadania, bardzo trudnego do praktycznej realizacji.

\section{Wnioski}

1. Problem zasad etycznych pracy archiwalnej nie przyciągał specjalnej uwagi polskich archiwistów i historyków, mimo że w roku 1996 na Międzynarodowym Kongresie Archiwów uchwalono Kodeks Etyczny Archiwisty. Został on w Polsce opublikowany, ale nie wywołał poważniejszej dyskusji, być może dlatego, że jego treść generalnie nie budzi wątpliwości. Jednak nie powinien być on uznawany za normatyw ostateczny, nie podlegający zmianom. Raczej należałoby go traktować jako punkt wyjścia do dalszych prac, zmierzających do jego dostosowania do specyficznych warunków poszczególnych krajów, aby mógł uzyskać w nich powszechne uznanie, lepiej służyć w pracy archiwistów i zwiększać świadomość odpowiedzialności archiwistów za wykonywaną przez nich pracę.

2. Kodeks etyczny może wpłynąć na większą świadomość archiwistów znaczenia stojących przed nimi zadań i wykonywanej pracy archiwalnej. Szczególnie lepsze zaspokajanie potrzeb użytkowników, wynikające $\mathrm{z}$ większego zaangażowania oraz kompetencji archiwalnych i historycznych pracowników archiwów, powinno w znaczący sposób wzmocnić prestiż archiwistów. Może to zachęcić środowiska naukowe do poszukiwania w archiwach partnerów do badań zespołowych w formie grantów badawczych. Natomiast obsługa bardziej przyjazna dla petentów niebędących badaczami na pewno wzmocni ich zaufanie nie tylko do archiwów ale także państwa i jego administracji, której działalność jest poddawana krytyce.

3. Wychodząc $\mathrm{z}$ tego założenia w artykule uzasadniono potrzebę uzupełnienia polskiego kodeksu etycznego archiwistów o trzy zasady, które powinny zostać uwzględnione ze względu na istniejące potrzeby. Zgłoszone propozycje bynajmniej nie wyczerpują wszystkich możliwości dalszych uzupełnień, uwzględnia-

${ }^{53} \mathrm{http}: / /$ www.bialystok.ap.gov.pl/p,91,archiwa-rodzinne-punkt-konsultacyjny (dostęp: 27.07.2019).

${ }^{54} \mathrm{http}: / / w w w . r z e s z o w . a p . g o v . p 1 /$ rodzinne/ (dostęp: 27.07.2019).

${ }^{55}$ Archiwa rodzinne. Zostań rodzinnym archiwista, Warszawa 2013; A. Konstankiewicz, Lubelskie archiwa rodzinne, Lublin 2015. 
jących specyfikę polskich archiwów. Autor ma nadzieję, że jego tekst stanie się bodźcem do dalszych analiz, w których wyniku zostaną zgłoszone kolejne propozycje uzupełnienia zbioru pryncypiów etycznych obowiązujących w naszym środowisku archiwalnym.

4. Koniecznie należałoby uznać pracę archiwalną jako służbę na rzecz państwa i obywateli, wymagającą od archiwistów szczególnego zaangażowania oraz odpowiedzialności. Dokumentacja, którą przechowuje się w archiwach, posiada wielką wartość dla wszystkich polskich obywateli, umożliwiając badania nad historią Polski, a także zaspokajając ich potrzeby informacyjne i dokumentacyjne. A archiwiści są jej depozytariuszami i strażnikami. Problem sposobu wypełniania tej służby przez archiwistów we współczesnych warunkach nie należał do przedmiotu tego artykułu, ponieważ wymaga oddzielnego i obszernego opracowania o charakterze analitycznym.

5. Ze względu na duże zainteresowanie historią w naszym kraju i pokaźną liczbę użytkowników prowadzących poszukiwania w archiwach dla celów naukowych, ich personel powinien dążyć do udoskonalania pomocy informacyjnych, istniejących w archiwach, szczególnie w odniesieniu do zespołów najcenniejszych i najczęściej wykorzystywanych w procesie udostępniania. Dzięki temu kwerendy przeprowadzone przez badaczy i użytkowników nieprofesjonalnych będą efektywniejsze, co powinno pozytywnie wpłynąć zarówno na wyższy poziom badań historycznych jak i lepsze zaspokajanie indywidualnych potrzeb informacyjnych obywateli, prowadzących poszukiwania w archiwach.

6. W rękach osób prywatnych znajduje się wartościowa dokumentacja dotycząca ich samych jak również rodzin, z których pochodzą oraz innych osób. W przypadku śmierci tych posiadaczy zdarza się, że materiały ulegają zniszczeniu lub rozproszeniu, dlatego archiwa powinny zostać zobowiązane do wykazywania stałej troski o nie oraz przejmowania ich na warunkach uzgodnionych z właścicielami. Gdyby okazało się to niemożliwe, należałoby oczekiwać od archiwów, aby zrezygnowały z zamiaru przejmowania oryginałów, natomiast wykonały za zgodą właścicieli na swój koszt kopie cyfrowe dokumentacji znajdującej się w posiadaniu tych osób i udostępniały w przyszłości na ustalonych z nimi zasadach wszystkim zainteresowanym.

\section{REFERENCES / BIBLIOGRAFIA}

\section{Źródła}

Dz. U. z 2008 r. nr 227, poz. 1505; z 2016 r. poz. 125, z 2018, poz. 2096. http://sap.waw.pl/wp-content/uploads/u1/kodeks.pdf (dostęp: 14.07.2019).

http://www.adok.ru/about/ (dostęp: 17.07.2019).

http://www.zakonprost.ru/content/base/part/323656 (dostęp: 17.07.2019).

https://vsa-aas.ch/beruf/ethikkodex/ (dostęp: 18.07.2019)

https://www.archives.org.uk/images/ARA_Documents/ARA_Code_Of_Ethics.pdf (dostęp: 17.07.2019). 


\section{Opracowania}

Archiwa rodzinne. Zostań rodzinnym archiwista, Warszawa 2013.

Bez taryfy ulgowej. Dorobek naukowy i edukacyjny Instytutu Pamięci Narodowej 20002010, red. A. Czyżewski, S. M. Nowinowski, R. Stobiecki, J. Żelazko, Warszawa 2012.

Brzeziński Tadeusz, Etyka lekarska, Warszawa 2002.

Dingwall Glen, Trusting Archivists: The Role of Archival Ethics Codes in Establishing Public Faith, „The American Archivist”, Vol. 67, 2004, Issue 1, p. 10-30.

Dokumenty powstania styczniowego: wydarzenia - ludzie - tradycja, red. P. Dymmel, R. Hordyjewski, Lublin 2013.

Encyclopedia of Archival Science, ed. Luciana Duranti, Patricia C. Franks, Lanham 2015. Etyka w biznesie, red. P. M. Minus, tłum. E. Balcerek, Warszawa 1998.

Gontarczyk Piotr, Polska Partia Robotnicza. Droga do władzy (1941-1944), Warszawa 2006.

Gontarczyk Piotr, Poprawianie historii PPR. Metody fatszowania źródet historycznych w pierwszej edycji dokumentów PPR, „Biuletyn Instytutu Pamięci Narodowej”, 1-2, (2005) s. 33-49.

Górniak Jarosław, Tożsamość narodowa a tożsamość polska, w: Tożsamość europejska a tożsamość polska, Warszawa 2005, s. 11-30.

Izdebski Hubert, Etyka prawnicza: stanowiska i perspektywy, Warszawa 2008.

Jarysz Aleksandra, Dzieło sztuki na granicy przeszłości i przyszłości. Historia i patriotyzm w sztuce nieprofesjonalnej, „Sprawy Narodowościowe. Seria nowa”, 47 (2015) s. 106-114.

Kielanowski Tadeusz, Etyka i deontologia lekarska, red. J. Bogusz, Warszawa 1985.

Kajta Justyna, Mrozowicki Adam, Strategie życiowe robotników po 1989 roku - praktyczne i etyczne wyzwania kolekcji danych biograficznych, ,Studia Socjologiczne”, 214 (2014) z. 3, s. 239-256.

Kamiński Łukasz, Czy potrzebna jest instytucja pamięci? w: Dziennikarz - między prawda a kłamstwem. VII Ogólnopolska Konferencja Pamięć i tożsamość Polaków-dziś, Łódź 2013, s. 26-33.

Kodex etických zasád pro archiváře, „Archivní Časopis”, 48 (1998) s. 1-3.

Kolankowski Zygmunt, Kilka uwag wstęnych w sprawie etyki zawodu archiwisty, „Archiwista", 8 (1972) nr 2, s. 19-22.

Konstankiewicz Agnieszka, Lubelskie archiwa rodzinne, Lublin 2015.

Matelski Dariusz, Problem restytucji polskich dóbr kultury od czasów nowożytnych do współczesnych. Archiwa - księgozbiory - dzieła sztuki - pomniki, Poznań 2013.

Matuszak Renata, Etyka a zawód archiwisty, „Piotrkowskie Zeszyty Historyczne”, 11 (2010) s. 207-222.

Mazur Zbigniew, Wawruch Krzysztof, Niemieckie komponenty w świadomości historycznej studentów Ziem Zachodnich i Pólnocnych, ,Zeszyty Instytutu Zachodniego”, 26, (2002) s. 21-23.

Michalski Łukasz, Świadomość historyczna uczniów szkót ponadpodstawowych $w$ aglomeracji warszawskiej. Raport z badań, Warszawa 2015.

Mikołajczyk Magdalena, Jak się pisało o historii... Problemy polityczne powojennej historii Polski w publikacjach drugiego obiegu w latach siedemdziesiatych i osiemdziesiatych, Kraków 1998.

Olejnik Stanisław, Etyka lekarska, Katowice 1995.

Osiński Zbigniew, Nauczanie historii w szkołach podstawowych w Polsce w latach 19441989. Uwarunkowania organizacyjne i ideologiczno-polityczne, Lublin 2010. 
Piotrowska Monika, Sprawa zabójstwa Józefa Cechnowskiego w roku 1925 a rola Stanisława Radkiewicza, ,Zeszyty Naukowe UJ Prace Historyczne”, 144 (2017) z. 4, s. 645-667.

Płużański Tadeusz, Pokolenie AK i Żolnierzy Niezłomnych wzorcem dla dzisiejszej młodzieży, w: Dziennikarz - między prawdą a kłamstwem. VII Ogólnopolska Konferencja Pamięć i tożsamość Polaków - dziś, Łódź 2013, s. 123-129.

Pratley Peter, Etyka w biznesie, przekł. M. Albigowski, Warszawa 1998.

Rutkowski Tadeusz Paweł, Nauki historyczne w Polsce 1944-1970. Zagadnienia polityczne i organizacyjne, Warszawa 2007.

Sarkowicz Ryszard, Amerykańska etyka prawnicza, Kraków 2004.

Schalitt Elfriede, Auf dem Weg zur Archivethik für das Informationszeitalter. Der Kodex etischer Grundsätze für Archivarinen und Archivare im Kontext aktueller Informationsetischer Entwicklungen, „Informationswissenschaft: Theorie, Methode, Praxis”, 2016, s. 24-59.

Sitek M, Tożsamość narodowa (europejska) a obywatelstwo Unii Europejskiej, „Journal of Modern Science", 4 (27), 2015, s. 122-123. (http://www.jomswsge.com/Tozsamosc-narodowa-europejska-na-obywatelstwo-Unii-Europejskiej,80584,0,1.html (dostęp: 27.07.2019).

Składanowski Henryk, Stosunki polsko-sowieckie w programach nauczania i podręcznikach historii w szkole powszechnej (podstawowej) w Polsce w latach 1932-1956, Torun 2004.

Skowronek Jerzy, Głos w dyskusji o „Kodeksie etycznym archiwisty”, „Archeion”, 94 (1995) s. 362-365.

Skowronek Jerzy, Misja archiwisty i problemy rewindykacji archiwaliów - Specyfika Europy Środkowo-Wschodniej XIX i XX w., „Archeion”, 94 (1995) s. 7-21.

Stownik języka polskiego PWN, red. M. Szymczak, t. 3, Warszawa 1998.

Sobiech Ryszard, Analiza badań społecznych na temat wizerunku stużby cywilnej oraz opracowania rekomendacji dla przyszłych badań, Warszawa 2009.

Stępniak Władysław, Etyczne aspekty zawodu archiwisty, „Archiwista Polski”, 1 (1997) nr 1, s. 15-17.

Ścigaj Paweł, Tożsamość narodowa. Zarys problematyki, Kraków 2012.

Tokarczyk Roman, Etyka prawnicza, Warszawa 2006.

Wojdon Joanna, Propaganda polityczna w podręcznikach dla szkót podstawowych 19441989, Toruń 2001.

Wysocki Artur, Stosunek społeczeństwa polskiego do przeszłości a tożsamość narodowa. Analiza badań sondażowych, „Annales UMCS”, sec. I, 43 (2018) nr 1, s. 111-123.

Zalewski Bohdan, Rola historii polskiej marynarki wojennej $i$ historii wojen morskich w ksztatceniu oficerów, w: Kształtowanie świadomości historycznej żotnierzy, red. J. Karwat, Warszawa-Poznań, 2002, s. 76-88.

Żaryn Małgorzata, Polityka historyczna w edukacji PRL, w: Polityka czy propaganda. PRL wobec historii, red. P. Skibiński, T. Wiścicki, M. Wysocki, Warszawa 2009, s. $117-142$. 


\title{
THE PROBLEM OF ETHICAL PRINCIPLES IN THE WORK OF POLISH ARCHIVISTS
}

\begin{abstract}
Adopted in 1996 at the International Congress on Archives in Beijing, the ICA Code of Ethics was embraced by the Polish archivist community without attracting any criticism. This paper seeks to justify the need to create an individual code of ethics for Polish archivists on the basis of the international one and supplement it with three additional principles. Due to the great value of the documentation stored in Polish archives, archival work should be considered a service for the state and citizens, which requires archivists to exhibit the utmost degree of commitment and responsibility. Archive staff should strive to improve the information aids that exist in the archives, especially with regard to the most valuable and accessible material, in order to adequately fulfil the individual information needs of citizens who search the archives. State archives should also be obliged to undertake actions aimed at securing valuable files owned by private persons and taking them over on terms agreed with the owners. Should this prove impossible, archives could attempt to digitalise such material with the owner's consent and make them available on the agreed terms.
\end{abstract}

Keywords: ethics; ethical principles; archivist work; Polish archives, archivists 